\title{
ICT and home-educating families: a qualitative multiple case study
}

\author{
Angélica Pineda Franky ${ }^{a}$ \\ Andrés Chiappe ${ }^{b}$
}

\section{Abstract}

While education is being increasingly permeated by Information and Communication Technologies (ICT), the current school is considered outdated and hardly capable of responding to the challenges of our time. Home Education emerges as a growing alternative, especially in developing countries, where it is not yet properly regulated and developed. This article presents a qualitative multiple case study focused on exploring the use of ICT by 70 Colombian families who educate at home. Data analysis was conducted following Grounded Theory's steps from human, educational and technological dimensions. The results show that, within a context of constant social pressure, parents conceive ICT as mediators that allow them to access open support communities and resources, in order to develop their own guiding skills, enhance the development of their children's talents, mainly through gaming, collaboration, research and outdoor exploration. This becomes a lifestyle that ends up changing their relationships and family dynamics.

Keywords: Homeschooling. ICT. Educational Technology. Unschooling. Family Relationships.

\section{Introduction}

It is well known that the dynamics of today's world are diverse, changing and sometimes very difficult to understand and predict (ROTH, 2014). A constant change wrap up $21^{\text {st }}$ century citizens who are challenged and impacted by new ways of thinking, feeling and behaving (KAY; GREENHILL, 2011).

As part of the current social and cultural scenario, it is noteworthy the high impact that Information and Communication Technologies (ICT) have been generating

\footnotetext{
a Universidad de La Sabana. Chía, Cundinamarca, Colombia.

b Universidad de La Sabana. Chía, Cundinamarca, Colombia. 
on human interactions and relationships on a daily basis, especially on Education (SEDDON, 2015; SILVA, 2011). In this regard, it is worth mentioning that today's education is in crisis (KRSTIĆ, 2016). Traditional schooling is seriously questioned among others for its lack of flexibility, its homogenizing spirit and the significant spoilage of children's creativity (AQDA; HAMIDI; RAHIMI, 2011). Thus, a lot of voices are rising today claiming for a change or transformation in Education in order to enhance the diverse talents of every single human being (SUMMO; VOISIN; TÉLLEZ-MÉNDEZ, 2016).

Additionally, $97 \%$ of current information in the world is now digitized, which has led to the emergence of new educational interactions sharped by an increasing flow and production of digital knowledge, freely available through global networks (LIBEN-NOWELL; KLEINBERG, 2008). In that way, communication in digital environments makes possible like never before the exchange of information widely, where the power of choice is one of the most important determining factors of human interaction in a globalized and interconnected world (HASTIE; DAWES, 2010).

In this context, new challenges constantly emerge for parents, students and teachers toward the building of new and pertinent ways of learning (WESTRICK; MORRIS, 2016).

Regarding the above, it is appropriate to recognize that the use of digital technologies is a growing and structural phenomenon in $21^{\text {st }}$ century education (DONG; NEWMAN, 2016). Although we can not ignore that the use of ICT brings both advantages and disadvantages in terms of social interaction, digital security and other socio-cultural issues of great importance, we must emphasize that the potential of ICT's audiovisual communication take advantage of the use of different tools, languages and codes, providing new spaces of interaction and alternative ways to educate far beyond the borders of traditional schools (HERRERA; FERNÁNDEZ; SEGUEL, 2018; KELLY, 2013).

One of such alternative ways is called Homeschooling or Home Education and is defined as a process of children's educational guidance, mainly led by their parents at home, avoiding the compulsory attendance to school and giving the family a prominent role (CARPENTER; GANN, 2016), where parents put their presence, care and love at the service of enhancing the talents of their children (MULYADI, 2010). Besides the above, homeschooling families choose to take responsibility for their children's education, either by providing teaching themselves, by hiring teachers to provide partial or complete education at home or by enrolling children in distance education institutions (ELIZALDE et al., 2012). 
There are several motivations and reasons that conduct the family to make the decision to educate their children at home, such as religious beliefs, dissatisfaction with the educational system, geographical distance to schools or, in other cases, the intention of protecting children from adverse or hazardous environments (RAY, 2015).

According to García (2011), although in Europe homeschooling does not have a widespread acceptance, especially due to concerns about child home abuserelated phenomena or about limiting the role of women in society, the numbers reported in the United States and Canada indicate a growing trend on this matter in the continent. This has a direct correspondence with the evolution of home education in Latin America and more specifically in Colombia, where it has been gaining much space as a growing educational alternative to traditional schools.

Furthermore, considering the importance of research on the impact of ICT use in Home Education, it is clear that this approach could be taken from multiple and interesting perspectives, thus, we have decided to focus primarily on three main dimensions: human, pedagogical and technological, and then address specific aspects of each one. Those aspects were: first, motivations, expectations and awareness of personal and family life about home education; second, educational challenges regarding the strengthening of skills required to be competitive in the near future adult's world (VELEZ, 2012) and, finally, the potential and risks of using digital technologies for children's education at home.

Therefore, a study was conducted with the purpose of exploring and documenting the experiences of 70 Colombian families who have used ICT in their home education practices.

\section{Method}

This research was conducted as an eminently qualitative process, supported with some quantitative information, in order to enhance the analysis of the data.

According to McMillan and Schumacher (2014),

Qualitative research describes and analyzes the social, collective and individual behaviors, opinions, thoughts and perceptions. The researcher tries to explain a phenomenon according to the values that people expose. Qualitative studies are important to create theory, develop some standards, the progress of educational practice, the explanation of social issues and encouragement of conduct (p. 400). 
This research has been defined as a multiple case study, in which although there is not necessarily a comparative intent (STAKE, 2013) which is allowed through a whole analysis, it is possible to accumulate enhanced data to provide complementary information and to find patterns supported by data from various sources, with similar characteristics. For the purposes of this study, each family provided data as a particular case which was analyzed using Grounded Theory. According to Glaser and Strauss (2009), Grounded Theory allows us to approach the phenomena of study directly from real data, leaving aside (but not completely) personal biases or categories of default analysis (HENNING; ROZO; SEGOVIA, 2016), leaving the same data routed in the process of collecting and analyzing information in a more natural way.

This methodological design is also considered relevant, given the purpose of identifying the effects of using ICT in multiple experiences in Home Education regarding human, educational and technological perspectives.

\subsection{Research Phases}

The study was conducted through four phases following the research design traced by Vaughn at al. (2017) and by Lien and Huang (2017) regarding multiple case studies in which Grounded Theory were applied. These phases included activities related to systematic literature review, design and validation of data collecting instruments, interviewing and applying of online surveys, triangulation, and data analysis using Grounded Theory. The synthesis of those phases is shown in Figure.

\subsection{Sampling}

In Colombia, many of the families that have made the decision to educate at home are part of the Colombian Network of Home Education Families, which has over 2,000 families who have chosen such way to educate their children. After a process of awareness and invitation, some of those families $(n=70)$ showed interest in participating in the study and consequently signed the corresponding informed consent. This way of forming the participating group of families was mentioned by Albuquerque, Lucena and Lins Neto (2014) as a non-probabilistic and intentional sample.

\subsection{Data collection}

The data was collected on the basis of the application of three instruments or techniques: an online survey, focus groups and a field diary. The survey consisted of 18 open-ended questions and 4 multiple-choice questions to inquire, on the one hand, about motivations, expectations, needs and risks of home education, and on 


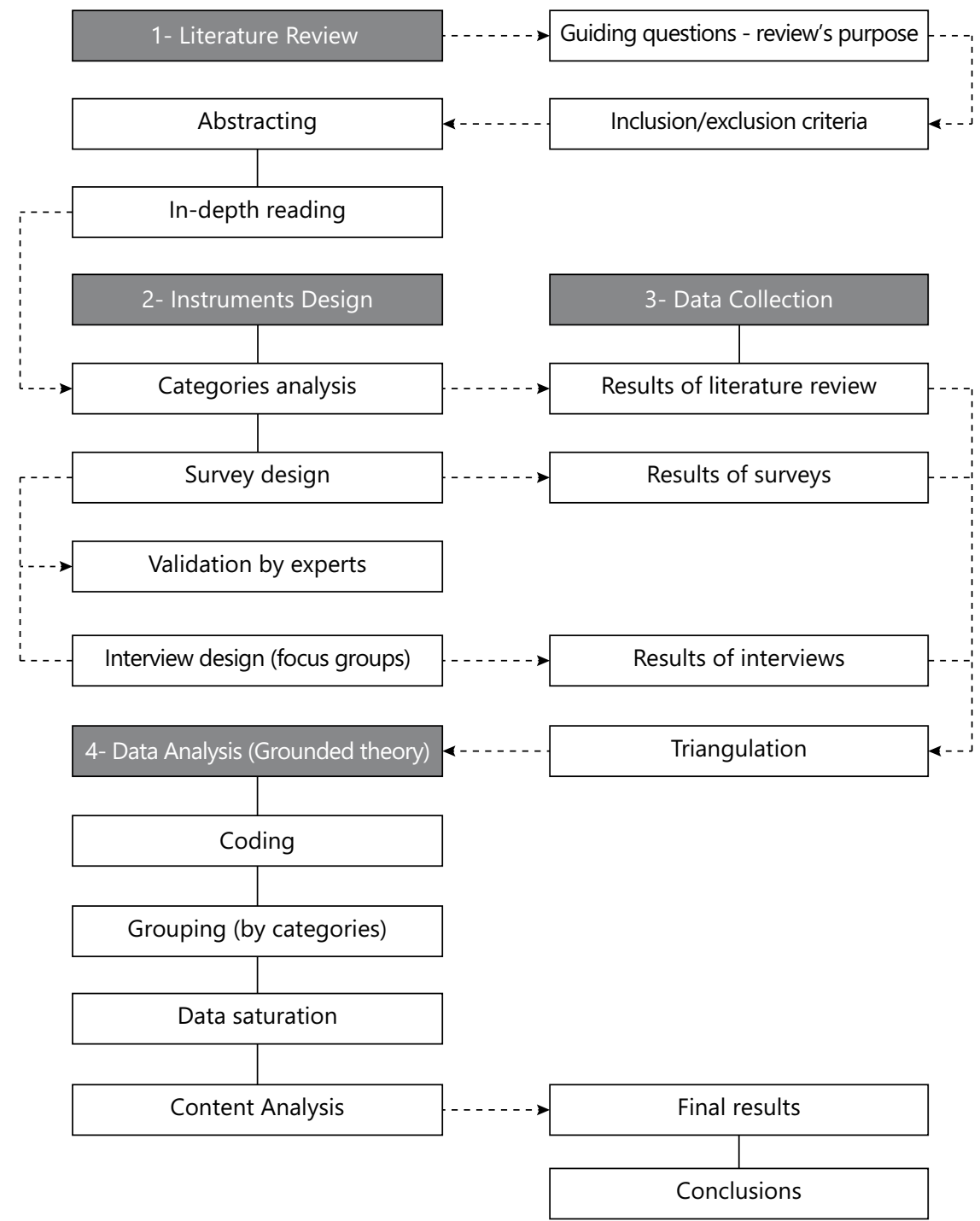

Source: Own elaboration (2017).

Figure. Phases of research.

the other hand, to inquire about teaching and learning strategies deployed at home, the use of ICT and the educational resources involved in this educational practice.

Complementary to the surveys, two face-to-face and four online focus groups were conducted, using virtual interaction spaces provided by the Colombian National 
Academic Network of Advanced Technology (RENATA). For each one of the focus group conversations, researchers informed and asked the participant for authorization to record the sessions; for this purpose, a consent was requested and signed. Such conversations were guided based on the same categories and defined questions of the surveys, in order to collect and analyze the same key ideas and topics.

Finally, the field diary, as a third instrument of data collection, allowed us to address the triangulation process in which the observations and reflections of the research team were documented and contrasted with the results of both surveys and focus groups.

\subsection{Data Analysis}

The analysis of data was conducted following the guidelines of Glaser and Strauss (2009) in relation to the processes of open, axial and selective coding in which the grouping of data was made based on the identification of meaning similarities or differences.

Later, this process was transformed into a categorization exercise that allowed the identification of particularly relevant information, which could be processed (data saturation) in order to generate substantive theory. The final phase of data analysis was made based on the open-ended and focus group questions using text mining tools such as QDA Miner 4 Lite, which enabled key ideas to be traced on the basis of frequencies and prominences (EMMETT, 2016).

The categories of analysis used both for human, educational and technological dimensions are shown in Table 1.

Table 1. Data analysis - dimensions and categories.

\begin{tabular}{lc}
\hline Dimensions & Categories \\
\hline Human & Expectations \\
& Motivations \\
& Risks \\
Educational & Educational needs \\
& Challenges \\
& Teaching and learning strategies \\
Sechnological & Support of ICT \\
& Family Considerations Regarding the Use of ICT \\
& Educational ICT-based content \\
Digital Educational Resources
\end{tabular}

Source: Own elaboration (2017). 


\section{Results}

\subsection{Results about human dimension: children's talents, the most important of all}

When parents decide to educate at home, different challenges appear related to their teaching skills and experience (CABO, 2012). Home educating parents need guidance and support to assume this huge responsibility in which children are both inspiration and main actors and parents are only change agents in the educational process.

The results showed that there are diverse resistances and claims from parents about the traditional educational system. Parents who educate at home believe that there is no direct equivalence between education and school, or that the last one is a rigid teaching-centered elaboration of an authoritarian model that does not allow for the improvement of children's emotional development and talents.

It was interesting to note that $20 \%(\mathrm{n}=28 ; 14$ families $)$ of the parents who participated in the study consider Home Education as a possibility of orientation toward self-knowledge, strengthening self-esteem and the need to be the children themselves who discover what they really care about their lives, and that this has a special relationship with happiness and autonomy.

One of those parents (in focus group \#4) stated that:

Today I realize that what I have achieved is an "enormous autonomy", a great love of learning, uh, a guy who generates questions and tries to solve them by himself, and that is interested! He is motivated by learning, not because it was compulsory, but because it is interesting. I think that from Home Education we can make a revolution of the general educational model. [...] There are other ways of learning that are more effective, more efficient and more fun (focusGr\#4).

In the same focus group, another parent states: "I had also raised something, that the school, eh... has a homogeneous curriculum for heterogeneous people." "Undoubtedly, knowledge... comes out of motivation."

Another interesting result related with the human dimension was focused on the ability of the traditional educational system to provide personalized learning and to enhance children's talents. Regarding the above, a parent (in focus group \#2) indicated: 
For us, the traditional system fails to provide quality education, truly centered on the child and his talents, in the development of his being. It is an obsolete, often aggressive, system that conducts the child into an education based on having, and not in being a good person (focusGr\#2).

In addition, other parents (from interviews \#1 and \#5) indicated:

I would say that the reason that motivates a parent to home educate is the nonconformity with the traditional system and what it offers. Long time in school places and classes is not worth the low salaries and the scarce job opportunities. A system created to be part of the workforce" [...] The traditional educational system is not adapted to the needs of the child and the families, it is a system created with lack of inclusion (int\#1-int\#5).

\subsection{Results about human dimension: family relationships}

Triangulation of data indicates that Home Education makes some changes in families' dynamics and relationships.

Regarding this, the integration of other relatives and family members takes special importance in Home Education, as well as its recognition as a family right and as a significant response to a life project contemplated in the family core. Donnelly (2012) assures that Home Education is a right, because it is the parents who define the destinies of their family, and they must protect the duties and rights of their children, being this a family decision in which both family and society are involved.

In relation to this, $100 \%(n=70)$ of the families involved in this study reported the relevance of the participation of diverse family members in the educational process and the effect this entails in the family's relationships. About this, in an extract of interview \#1, the following was said:

Let's say that learning here begins to make sense when the child can see that his parents are involved in the process. Also when the parents give an example of commitment when they are beside the child helping him to achieve the goals set during the year... We believe that teachers must know everything and transmit everything, but education involving the emotional affection from parents is also transformative and can further strengthen technical knowledge (int\#1). 
Besides the above, data shows a relevant role of women in Home Education. Women are both mainly involved in the child raising process and in the teaching and learning process.

Regarding the participant families, in $69 \%$ of them, the educational process was accompanied mainly by the mother, in $10 \%$ by the father, and in the rest by other people who are not the children's parents, like tutors or external teachers.

In addition to the above, a participant of focus group \#1 said: "Home Schooling allows uncles, aunts and grandparents to become involved in the learning of children and, equally, to participate in the community with other ways of learning from everyday life."

Likewise, the following was said:

Home schooling rather than a school allows father and mother to tell you where to go, what to do and what not to do in a scenario of collective construction which should be based on love, respect, attention, recognition and valuation that each member of the family can contribute. As parents we cannot believe that we direct the destiny of our children, but we all build life itself (focusGr\#1).

Notwithstanding the above, not all the results that have to do with family relationships are positive. At this point, an issue that stands out in the analysis of focus groups data has to do with the tensions that emerge between the constant parental involvement in the education of children and the economic situation of the household. This tension arises from the need that exists in these families that one parent is dedicated to the education of the children and the other supports the family's economic income. In this sense, many families in the study $(n=49$; $70 \%$ ) report their quest for more well-off lifestyles, independent job options, or family projects in order to relieve domestic economic struggling. In relation to the above, in interview \#1 it was said that, at the family level, they work on a project that allows them to be independent and participate in a productive family project: "my son and daughter help me make the bills, take the orders, so from now they learn from the example of their parents."

Additionally, parents mention other challenges faced by them in the home educating process: financial sustainability for the family (42\%); socialization process with other children (7\%), fears for the future $(60 \%)$, legislation and state support $(24 \%)$. 


\subsection{Results about human dimension: social pressure}

Home Education families permanently move between educational system's objectives and social recognition (NEUMAN; GUTERMAN, 2017).

In relation to this, a large family who participated in this study indicated:

We have had a lot of family pressure, especially because first, having seven children is not very normal in our context, and second, having seven children out of school is crazy! You must handle this situation with great strength and, especially, with love and family union. There is no other way. We must shield ourselves as a family, so that, in some way, we will not be affected... To ensure that we are giving good and complete education to our children (int\#3).

In addition to the above, a participant of focus group \#2 commented:

[...] There are also challenges with opinions and concepts created by the rest of the community and society. People think that home education is strange. It is not easy to understand it as a style and a philosophy of life. There are challenges for kids too, because they are seen as different from the rest of their friends and children of their age. Everyone goes to school and they don't (focusGr\#2).

\subsection{Results about educational dimension: diversity in practice}

The results show that, $57.7 \%$ of the parents participating in the virtual survey affirmed that they are doing Home Education in a semi-structured style.

This type of semi-structured practice includes free activities such as gaming, sports and artistic activities, recognizing tastes, preferences, learning styles and talents, with a permanent exploration between parents and children, finding projects and subjects that are part of the learning process. A blended path follows topics, projects and some curricula and explores other kinds of activities that promote talent development in children.

On the other hand, $23.1 \%$ of the participants of this study say they do not follow any curriculum or schedule, in a highly exploratory and free-style home education. In this kind of approach parents become coaches, facilitators and partners of learning. Children explore, research and learn according with their 
own goals and feelings. These parents believe that it is not necessary to conduct the learning process, and children could explore and discover what they need to learn according to their own path and moment in life.

In contrast to the above, $19.2 \%$ of participating parents have decided to follow formal curricula in structured models. These include educational offers from online schools that have synchronous and asynchronous schedules, supported by digital platforms with interactive contents. This homeschooling approach allows parents to have more free time for themselves compared with other home education styles.

According to this, Elizalde et al. (2012) assert that ICT have achieved "diversity and hybridization of the Home Education", moving to a growing supply of online schools that offer curricula, resources, and instructional materials guided by technologies that do not take away the benefits of Home Schooling.

\subsection{Results about educational dimension: home educator skills}

Results show it is necessary for home educating parents ( $74.3 \%$ of parents refer to it) to develop new skills and prepare themselves for the challenges related with Home Education, and also it is very important to generate contact networks with others parents to share knowledge and experiences. In that way, some parents can help to teach other children about subjects that their parents do not know, thus optimizing the knowledge and talents inside the network. According to this, in interview \#3 the following was mentioned:

I would say... Networking skills. Often, I couldn't teach my children everything they wanted to know, so I had to seek out people who knew those things and network with them, and teach their children what they wanted to learn. This means finding mentors in many skills, and that will require networking skills. I think it would help to have some kind of research skills, both on the internet and offline, because if your kids are going to ask you questions that you will love to answer, you will be able to find some resources for them, to answer those questions. And also multitasking. You must be able to multitask, that is going to make you happy. Some things have to be done, other things have to be prioritized, and others things to be put off for another day (int \#3). 


\subsection{Results about educational dimension: teaching-learning strategies}

Results show a great diversity of teaching and learning strategies that parents apply with their children at home. Regarding this, it is noteworthy the relevance of gaming and experiential learning in which ICT have an important support and interaction role. The main kinds of teaching or learning activities referred by parents are shown in Table 2 .

Regarding the above, a parent in interview \#5 of May 24, 2016, indicated:

Combining play, sporting, artistic and learning activities outside home allows children to develop learning and socialization processes very well, other days they rely on educational technology platforms from home (int\#5).

As De-Marco, Garcia -Lopez and Garcia-Cabot (2016) assert, gaming allows the interaction of learners with their symbolic universe, where there are also rules, emotions, desires, and aspirations. The game then fosters self-knowledge, problem solving, critical thinking, solidarity, and other behaviors.

Likewise, taking advantage of the tools provided by technology, the use of digital educational resources and virtual learning environments are ultimately a strategy for teaching and learning in home-educated families. To really achieve powerful and significant learning in Home Education, digital learning environments and digital educational materials and contents are blended and complemented

Table 2. Teaching and learning focus.

\begin{tabular}{lc}
\hline Teaching-learning focus & $\%$ \\
\hline Gaming & $22.24 \%$ \\
Reading and library visits & $13.14 \%$ \\
Outdoor exploration & $15.16 \%$ \\
Using technological tools & $12.13 \%$ \\
Guides and educational material & $16.17 \%$ \\
Lectures and complementary classes & $5.5 \%$ \\
Research & $4.4 \%$ \\
Home school networking & $3.3 \%$ \\
Religious or spiritual activities & $2.2 \%$ \\
\hline
\end{tabular}

Source: Own elaboration (2017). 
with experiences, visits, games, socialization, among others. As Means et al. (2013) affirm, the hybrid learning environments that are effective for learning integrate spaces and times in which online learning, face-to-face and autonomous work are used.

\subsection{Results about technological dimension: ICT as mediators of learning}

One of the most significant findings in the present study regarding the use of ICT in Home Education is their role as facilitators of the educational practice for home educating parents.

All participants $(\mathrm{n}=70 ; 100 \%)$ felt that digital technologies are tools that make the world available. In that sense, they are considered necessary in education because they bring information on time and facilitate children's interaction and contact with knowledge.

According to the World Economic Forum Report (SCHWAB; SALA-I-MARTIN, 2015), Information and Communication Technologies help to close gaps in skills development and become facilitators of educational processes by helping to empower the skills needed for $21^{\text {st }}$ century citizens such as creativity, communication, persistence, collaboration and critical thinking.

Regarding this, a parent in focus group \#2 mentioned:

ICT do not fill the process, because they generate more questions. That is, the child that faces an app or a software program, although the software guides him towards certain processes, will eventually have more questions to be answered (focusGr\#2).

On the other hand, it is recognized by the vast majority of the parents participating in the study $(\mathrm{n}=68 ; 97.1 \%)$ that ICT is part of today's life and that this brings new ways of learning, where audiovisual language, social network interaction and new ways of communicating generate more free and autonomous learning opportunities.

In this regard, Berríos-Valenzuela, Buxarrais-Estranda and Garcés (2015) indicate that ICT not only act as mediators of learning processes, but also help to mediate the relationships between the parent-educator, the content and the learner, being also part of the configuration of learning environments through 
communication and collaboration. An issue that arises from this aspect is that parents who educate at home find in virtual-online environments a viable option to enhance teaching and learning.

\subsection{Results about technological dimension: resources for learning}

It is a common practice in Home Education to get support in online schools. Table 3 shows the diversity of digital educational resources used by home education families.

McAvoy (2015) affirms that today the existence of ICT is part of the decision of many parents to educate at home, since they allow parents to feel more confident when they can access different tools, contents, and information to focus their children's education.

In this sense, a parent in focus group \#2 mentioned:

ICT are very useful because they give you the possibility to recover information and do some research about a fact or a subject. There are applications that allow you to go step by step in a project or technologies that make learning more meaningful, with more sense for the kids.

Beside this, in interview $\# 5$, the following was mentioned:

We love ICT. Technologies are unparalleled facilitators, incredible, but you have to know how to use them. They facilitate processes; they allow interaction, discoveries, innovations. They are resources that facilitate the process that we individually carry out in a family level. In our teaching and learning process, we discover as a family

Table 3. Digital educational resources used in Home Education.

\begin{tabular}{lc}
\hline YouTube videos & $\mathbf{4 0 . 4 \%}$ \\
\hline Free online courses & $25.0 \%$ \\
Online school platforms & $11.5 \%$ \\
Online educational services & $9.6 \%$ \\
Apps for mobile devices & $5.5 \%$ \\
Social networking & $9.6 \%$ \\
\hline
\end{tabular}

Source: Own elaboration (2017). 
a variety of tools, forms, videos, platforms, applications, texts, that make learning a very enriching experience (int $\# 5$ ).

\subsection{Results about technological dimension: the purpose of ICT}

Regarding the motivations to use digital technologies, $98 \%$ of parents who participated in the survey confirmed using the technologies in their home education experiences. On the other hand, $2 \%$ of participant parents considered that "technology takes children away from their environment and their natural context" and avoid their use at home.

Result shows that $48.1 \%$ of the parents who participated in the virtual survey of this research say that they use ICT in their teaching process just to access content and information, while $26.9 \%$ said that they innovate using ICT due to their capacity to produce knowledge products with their children. The remaining $25 \%$ of parents use ICT as a support tool for learning activities in a general way.

\subsection{Results about technological dimension: the risks of ICT}

Some parents find ICT to be risky, since they consider that they have a high potential for generating dependencies, especially through content exclusively aimed at leisure, videos without educational content and pages or platforms with risky content for their development from ethical, moral and intellectual perspectives.

In this regard, in interview \#4 the following was mentioned:

We have a concern about the issue of how much time children spend in front of a computer. We have found from literature that it depends on the learning context. And it has a lot to do with the perspective of the family regarding the accompaniment of the children. That is, there are many children and adolescents whose main and sometimes only companion is the computer. Yes? Children who have more support, who have more alternatives to learn, are the ones who have adults besides them, supporting their learning process and development.

On the other hand, it was found that there are numerous family considerations that are important related to the use of ICT in the Home Education. Among others, there were: parent supervision to regulate their use, the tendency of ICT to replace human interaction, the safety and integrity of children, the establishment of schedules, routines and parental controls mainly on daily contents and dynamics of interaction with ICT at home. 


\subsection{Results about technological dimension: about digital content}

Home educating parents reported in this study mainly the use of digital technologies as support for their teaching and learning activities. Results show that each family establishes their own learning environment, where there is a blend between faceto-face and ICT-based resources and spaces. A blended learning environment is common in the educational practice of home educating families because they access the internet for content but the learning process is combined with the living experience, which allows them to generate life learning that is more connected with reality, more alive, intense and reflective.

The ICT-based contents and educational resources most used by parents in Home Education are shown in Table 4.

All those resources conform what Jonassen and Land (2012, p. 3) define as a learning environment that "provide interactive, complementary activities that enable the individual to address unique learning interests and needs, study multiple levels of complexity, and deepen understanding".

Based on the information provided so far, it is possible to mention that, through appropriate accompaniment that includes reflection and orientation towards the critical use of ICT in learning, powerful educational processes that foster the development of children who are home-educated can be achieved.

Table 4. Content and educational resources.

\begin{tabular}{lc}
\hline ICT-based educational resources & $\%$ \\
\hline Educational platforms & $25.0 \%$ \\
Videos & $19.0 \%$ \\
Language learning resources & $15.0 \%$ \\
Search engines & $12.0 \%$ \\
Interactive online media & $10.0 \%$ \\
Games & $10.0 \%$ \\
Arts and music & $2.0 \%$ \\
Spiritual and religious content & $3.0 \%$ \\
Not use of ICT-based content & $4.0 \%$ \\
\hline
\end{tabular}

Source: Own elaboration (2017). 


\section{Discussion}

\subsection{Home Education as an alternative $21^{\text {st }}$ century way of life}

More than a way of teaching or learning, parents who educate at home express a particular interest in having a lifestyle based on freedom, respect, love and personal and family well-being, no matter the family structure or the plurality of philosophical, ideological or religious beliefs.

Therefore, there is in this group of families the intention to protect their children, to promote and develop their talents, to respect their tastes and choices and the intention to strengthen their self-esteem and their inner being, as well as following a trend of disconnection with the traditional educational models.

The search for new forms of economic organization is also part of this lifestyle where independence and family entrepreneurship are promoted through the creation of family productive projects. Additionally, as McAvoy (2015) asserts, the existence and presence of ICT in daily life and access to information through them permanently make the decision to educate at home more frequent and widespread.

Another reflection to note based on the results previously mentioned has to do with the efficacy of learning at home. It is taken for granted that the parents who educate at home want to educate in the best way, but this does not mean that they achieve it in practice and reality. The most important challenge is to face their deepest fears and manage them to revise their own life history, understanding that there is no better or worse way to educate, and that this is simply a moment in the lives of the people involved; a learning moment in family life. Home education, therefore, is not only a rebellious act against the school itself as an institution, but rather an act of brave parents who believe that it is time to transform their closest reality, their own family, assuming themselves the responsibility for this social and personal action.

In addition to the above, home education parents face their own paradigms and mental models, facing a process of unlearning. To unschool minds and habits means to change paradigms, a new perspective that challenge parents to become more flexible facing the new demands of our time.

Also, Home Education is an opportunity to promote learning at a family level, where each member of the family develops a particular learning process. In this regard, it is worth noting that not only parents but also other relatives such as 
grandparents and uncles, among others, play a relevant role in strengthening family ties and sibling relationships. In this context, each space, each activity provides an opportunity to learn.

\subsection{About the role of ICT: access and exploration}

ICT are considered key tools for home educating parents to recognize their opportunities for improvement, by identifying what makes content feasible and facilitating learning, ensuring appropriate accompaniment and allowing an approach to real life, via research, to explore and build knowledge.

Home Education is still an emerging educational practice with great possibilities for growth and expansion due to the evolution and educational integration of ICT. However, it is also necessary to recognize their implicit risks and possible barriers and face their introduction to Home Education in a critical and reflective way.

It is interesting to mention that the purpose of ICT usage in Home Education is not ultimately to transfer school to home, but to find new forms of collaborative, flexible, meaningful and personalized learning.

In this sense, this can be achieved if home educating families accomplish enough access to open resources, such as platforms, learning objects and other kinds of Open Educational Resources (OER).

Regarding the above, a final set of recommendations on this matter emerges, indicating the relevance of conducting processes of parent training on the effects and impacts of the use of technology for learning, a broader understanding of the effective use of ICT and its risks, the generation of ICT-based communities of practice in Home Education and the production of more research about teaching and learning with ICT at home. 


\section{Famílias que educam em casa com TIC: um estudo qualitativo de múltiplos casos}

\section{Resumo}

Enquanto a educação é cada vez mais permeada pelas Tecnologias de Informação e Comunicação (TIC), a atual instituição escolar é considerada desatualizada e quase incapaz de responder aos desafios do nosso tempo. A educação em casa surge como uma alternativa crescente, especialmente nos países em desenvolvimento, onde ainda não está devidamente regulada ou estruturada. Este artigo apresenta um estudo qualitativo de casos múltiplos focados na exploração do uso das TIC por 70 famílias colombianas que educam em casa. A análise dos dados foi realizada seguindo as etapas da Teoria fundamentada a partir das dimensões humana, educacional e tecnológica. Os resultados mostram que, em um contexto de pressão social constante, os pais reconhecem as TIC como ferramentas de mediação que lhes permitem acessar as comunidades e recursos abertos de apoio, desenvolver suas próprias habilidades de orientação e para melhorar o desenvolvimento de talentos seus filhos, principalmente através do jogo, colaboração, pesquisa e exploração ao ar livre. Finalmente, reconhece-se que esta forma de educar torna-se um modo de vida que acaba alterando as relações e as dinâmicas familiares.

Palavras-chave: Educação em Casa. TIC. Tecnologia Educacional. Não Escolaridade. Relacionamentos Familiares.

\section{Familias que educan en casa con TIC: un estudio cualitativo de múltiples casos}

\section{Resumen}

Si bien la educación está cada vez más impregnada de las Tecnologías de la Información y la Comunicación (TIC), la escuela actual se considera obsoleta y dificilmente capaz de responder a los desafíos de nuestro tiempo. La educación en el hogar surge como una alternativa creciente, especialmente en los países en desarrollo, donde aún no está debidamente regulada y desarrollada. Este artículo presenta un estudio cualitativo de caso múltiple enfocado en explorar el uso de las TIC en 70 familias colombianas que educan en el hogar. El análisis de los datos se realizó aplicando la Teoría Fundamental desde las dimensiones humana, educativa y tecnológica. Los resultados muestran que en un contexto de constante presión social, los padres usan TIC como mediaciones que les permiten acceder a comunidades y recursos de apoyo abiertos, para desarrollar sus propias habilidades orientadoras, potenciar el desarrollo de los talentos de sus hijos, principalmente a través del juego, la colaboración, la investigación y la exploración al aire libre. Finalmente, se reconoce que esta forma de educar se convierte en un estilo de vida que termina por cambiar las relaciones y dinámicas familiares.

Palabras clave: Educación en el Hogar. TIC. Tecnología Educativa. Desescolarización. Relaciones Familiares. 


\section{References}

ALBUQUERQUE, U. .; LUCENA, R. F. .; LINS NETO, E. F. Selection of research participants. In: ALBUQUERQUE U. P. et al. Methods and techniques in ethnobiology and ethnoecology. New York: Springer, 2014. p. 1-13.

AQDA, M. F.; HAMIDI, F.; RAHIMI, M. The comparative effect of computer-aided instruction and traditional teaching on student's creativity in math classes. Procedia Computer Science, v. 3, p. 266-70, 2011. https://doi.org/10.1016/j.procs.2010.12.045

BERRÍOS-VALENZUELA, L.; BUXARRAIS-ESTRADA, M. R.; GARCÉS, M. S. ICT use and parental mediation perceived by chilean children. Comunicar, v. 23, n. 45, p. 161-8, 2015. https://doi.org/10.3916/C45-2015-17

CABO, C. El "homeschooling” en España: descripción y análisis del fenómeno. 2012. 469 f. Dissertation (Doctor en Pedagogia) - Universidad de Oviedo, Oviedo, 2012.

CARPENTER, D.; GANN, C. Educational activities and the role of the parent in homeschool families with high school students. Educatioal Review, v. 68, n. 3, p. 322-39, 2016. https://doi.org/10.1080/00131911.2015.1087971

DE-MARCOS, L.; GARCIA-LOPEZ, E.; GARCIA-CABOT, A. On the effectiveness of game-like and social approaches in learning: comparing educational gaming, gamification \& social networking. Computers \& Education, v. 95, p. 99-113, 2016. https://doi.org/10.1016/j.compedu.2015.12.008

DONG, C.; NEWMAN, L. Ready, steady ... pause: integrating ICT into Shanghai preschools. Internatioal Journal of Early Years Education, v. 24, n. 2, p. 24-37, Feb. 2016. https://doi.org/10.1080/09669760.2016.1144048

DONNELLY, M. P. A global perspective on freedom in education through the eyes of the Homeschool Movement. University of St. Thomas Journal of Law and Public Policy, v. 7, n 1, p. 51-69, 2012.

ELIZALDE, M. Á. S. et al. Diversidad, participación y calidad educativas: necesidades y posibilidades del homeschooling/diversity, parent involvement and quality education: needs and possibilities of homeschooling. Estudios sobre Educación, v. 22, p. 55-72, 2012.

EMMETT, G. "Hands up, don't shoot" or shut up and play ball? Fan-generated media views of the Ferguson Five. Journal of Human Behavior in the Social Environment, v. 26, n. 3-4, p. 400-12, 2016. https://doi.org/10.1080/10911359.2016.1139990 
GARCÍA, E. F. Un mundo por aprender: educación sin escuela (ESE), autoaprendizaje colaborativo (AC) y educación en familia (EF). Bogotá: Universidad Nacional de Colombia, 2011.

GLASER, B. G.; STRAUSS, A. L. The discovery of grounded theory: strategies for qualitative research. New Brunswick: Transaction Publishers, 2009.

HASTIE, R.; DAWES, R. M. Rational choice in an uncertain world: the psychology of judgment and decision making. 2nd ed. Thousand Oaks: Sage, 2010.

HENNING, C.; ROZO, H.; SEGOVIA, Y. Training professors in ICT:

Personal learning environments: a grounded theory research study. Journal of E-Learning and Knowledge Society, v. 12, n. 1, p. 39-52, 2016.

HERRERA, M. A.; FERNÁNDEZ, D. C.; SEGUEL, R. C. Percepción de los profesores sobre integración de TIC en las prácticas de enseñanza en relación a los marcos normativos para la profesión docente en Chile. Ensaio: Avaliação e Políticas Públicas em Educação, v. 26, n. 98, p. 163-84, mar. 2018. https:// doi.org/10.1590/s0104-40362017002501119

JONASSEN, D.; LAND, S. Theoretical foundations of learning environments. 2nd ed. New York: Lawrence Erlbaum, 2012.

KAY, K.; GREENHILL, V. Twenty-first century students need 21 st century skills. In: WAN, G.; GUT (Eds.). Bringing schools into the 21 st century. [S.1.] Springer, 2011. p. 41-65.

KELLY, M. J. Beyond classroom borders: Incorporating collaborative service learning for the adult student. Adult Learning, v. 24, n. 2, p. 82-4, Apr. 2013. https://doi.org/10.1177/1045159513477844

KRSTIĆ, P. Three naive questions: addressed to the modern educational optimism. Studies in Philosophy and Education, v. 35, n. 2, p. 129-44, 2016. https://doi.org/10.1007/s11217-015-9463-6

LIBEN-NOWELL, D.; KLEINBERG, J. Tracing information flow on a global scale using Internet chain-letter data. Proceedings of the National Academy of Sciences, v. 105, n. 12, p. 4633-8, Mar. 2008. https://doi.org/10.1073/pnas.0708471105

LIEN, Y.-F.; HUANG, H.-M. Challenges in intergenerational caregiving for frail older people: a multiple case study: caregiving for older people. Nursing \& Health Sciences, v. 19, n. 1, p. 81-7, Mar. 2017. https://doi. org/10.1111/nhs. 12314 
MCAVOY, A. How are new technologies impacting elective home learners. In: ROTHERMEL, P. (Ed.). International perspectives on home-education: do we still need schools. New York: Palgrave Macmillan, 2015. p. 74-86.

MCMILLAN, J. H.; SCHUMACHER, S. Research in education: evidencebased inquiry. 7th ed. Edimburgh Gate: Pearson Higher, 2014.

MEANS, B. et al. The effectiveness of online and blended learning: A meta-analysis of the empirical literature. Teachers College Record, v. 115, n. 3, p. 1-47, 2013.

MULYADI, S. Effect of the psychological security and psychological freedom on verbal creativity of indonesia homeschooling students. International Journal of Business and Social Science, v. 1, n. 2, Nov. 2010.

NEUMAN, A.; GUTERMAN, O. What are we educating towards? Socialization, acculturization, and individualization as reflected in home education. Educational Studies, v. 43, n. 3, p. 265-81, May 2017. https://doi.org/10.1080/03055698.2016.1273763

RAY, B. D. Research facts on homeschooling. Salem: National Home Education Research Institute, 2015. Disponível em: $<$ http://eric. ed.gov/?id=ED556234>. Acesso em: 7 mar. 2017.

ROTH, R. Technology integration at a crossroads: dead end street or new horizons? The Online Journal of Distance Education and e-Learning, v. 2, n. 3, p. 103-31, 2014.

SCHWAB, K.; SALA-I-MARTIN, X. World Economic Forum's Global Competitiveness Report, 2014-2015. Geneva: World Economic Forum, 2015. Disponível em: <http://www3.weforum.org/docs/gcr/2015-2016/Global_ Competitiveness_Report_2015-2016.pdf>.Acesso em: 23 ago. 2017.

SEDDON, T. Re-making education in contexts of uncertainty: governing, learning and contextual understanding. Australian Educational Researcher, v. 42, n. 5, p. 527-48, 2015. https://doi.org/10.1007/s13384-015-0191-2

SILVA, A. C. Educação e tecnologia: entre o discurso e a prática. Ensaio: Avaliação e Políticas Públicas em Educação, v. 19, n. 72, p. 527-54, set. 2011. https://doi.org/10.1590/S0104-40362011000400005

SOTÉS ELIZALDE, M. A.; URPÍ, C.; MOLINOS TEJADA, M. C. Diversidad, participación y calidad educativas: necesidades y posibilidades del homeschooling/diversity, parent involvement and quality education: needs and possibilities of homeschooling. Estudios sobre Educación, v. 22, p. 55-72, 2012. 
STAKE, R. E. Multiple case study analysis. New York: Guilford, 2013.

SUMMO, V.; VOISIN, S.; TÉLLEZ-MÉNDEZ, B.-A. Creativity: central concept of education in the 21st century. Revista Iberoamericana de Educacion Superior, v. 7, n. 18, p. 83-98, 2016.

VAUGHN, M. et al. A multiple case study of teachers' visions and reflective practice. Reflective Practice, v. 18, n. 4, p. 526-39, 4 May 2017. https://doi.org/10.1080/14623943.2017.1323731

VELEZ, A. Preparing students for the future-21st century skills. 2012. $121 \mathrm{f}$. Dissertation (Doctor of Education ) - University of Southern California, Los Angeles, 2012.

WESTRICK, J. M.; MORRIS, G. A. Teacher education pedagogy: disrupting the apprenticeship of observation. Teaching Education, v. 27, n. 2, p. 156-72, 2016. https://doi.org/10.1080/10476210.2015.1059413

\section{Informações dos autores}

Angélica Pineda Franky: Academic Researcher in Home Education and ICT. Master in Educational Informatics at the Universidad de La Sabana. Contato: angelicapi@ unisabana.edu.co

Andrés Chiappe: Associate Professor at Center of Technologies for Academia of the Universidad de La Sabana. Chía, Cundinamarca, Colombia. Contato: andres.chiappe@ unisabana.edu.co 